\title{
ZMIANY OPROCENTOWANIA I WOLUMENU KREDYTÓW DLA PRZEDSIĘBIORSTW A ZMIANY STÓP PROCENTOWYCH NBP W LATACH 2008-2015
}

\author{
Sławomir Juszczyk \\ Rafał Balina \\ Katedra Finansów \\ Szkoła Główna Gospodarstwa Wiejskiego w Warszawie
}

\begin{abstract}
Abstrakt. Celem badań było ustalenie kształtowania się podstawowych stóp procentowych NBP i ich wpływu na zmianę wolumenu kredytów dla przedsiębiorstw niefinansowych w Polsce w latach 2008-2015. W trakcie analiz przedstawiono kształtowanie się zależności między wybranymi stopami procentowymi NBP, wolumenem kredytów udzielonych dla przedsiębiorstw niefinansowych oraz przeciętnego oprocentowania tych kredytów. W części badawczej za pomocą narzędzi statystycznych podjęto próbę ustalenia związków między zmiennymi. Uzyskane wyniki wskazały na występowanie silnej zależności między zmianami stóp procentowych NBP a oprocentowaniem kredytów dla przedsiębiorstw niefinansowych. Dodatkowo badania wykazały, że zmianom stóp procentowych odpowiadał nieadekwatny poziom zmian wolumenu udzielonych kredytów dla przedsiębiorstw sektora niefinansowego.
\end{abstract}

Słowa kluczowe: polityka pieniężna, stopy procentowe NBP, kredyty dla przedsiębiorstw

\section{WSTĘP}

Suma kredytów udzielonych przedsiębiorstwom niefinansowym przez banki może być cennym wskaźnikiem zmian gospodarczych w Polsce [Flejterski, Marcinkowska i Wdowiński 2014]. Wielkość akcji kredytowej skierowana do przedsiębiorstw może wpływać znacząco na ich rozwój, a to może wiązać się z powstawaniem nowych miejsc pracy oraz wzrostem PKB. Kredytowanie roz- 
woju przedsiębiorstw przez banki ściśle związane jest z kosztem kredytu, w tym z jego oprocentowaniem, które z kolei ustalane jest przez banki na podstawie stóp procentowych NBP oraz sytuacji na rynku [Iwanicz-Drozdowska, Jaworski i Zawadzka 2010]. Ponadto kluczowy wpływ na sytuację na rynku międzybankowym ma właśnie bank centralny, który za pomocą Rady Polityki Pieniężnej i posiadanych instrumentów oddziałuje na ten rynek i realizuje przy tym założone cele polityki pieniężnej. Po kryzysie z 2008 roku, polityce pieniężnej prowadzonej przez większość banków centralnych, w tym Narodowy Bank Polski, towarzyszy spowolnienie gospodarcze i tendencja do obniżania stóp procentowych w celu spowodowania ożywienia gospodarczego. Powinno to dawać szanse na rozwój przedsiębiorstw, gdyż powinno to się wiązać między innymi z obniżaniem stóp przez banki komercyjne i spółdzielcze a w konsekwencji zwiększać dostępność kredytów dla przedsiębiorstw niefinansowych [Juszczyk 2008]. Jednak w praktyce współzmienność ta nie zawsze jest natychmiastowa i taka sama co do wielkości zmian oprocentowania. W związku z tym zagadnienie wydaje się być ważne i ciekawe, również z poznawczego względu. Nasuwa się również pytanie - czy można przewidzieć, w jakim stopniu i po jakim czasie obniżenie podstawowych stóp banku centralnego wpłynie na obniżenie oprocentowania kredytów dla przedsiębiorstw oraz wzrost sumy tych kredytów. W tym artykule, na podstawie informacji rynkowych i literatury zagadnienia, podjęto próbę znalezienia odpowiedzi na powyższe pytanie.

\section{METODY BADAŃ}

W artykule przedstawiono kształtowanie się poziomu stóp procentowych NBP w latach 2008-2015 oraz sumy kredytów w walucie polskiej dla przedsiębiorstw niefinansowych a także ich średnie oprocentowanie w latach 2008-2015. Dane niezbędne do wykonania badań pochodziły m.in. z raportów Narodowego Banku Polskiego. Dotyczyły one kształtowania się stóp procentowych NBP, oprocentowania kredytów dla przedsiębiorstw niefinansowych oraz skumulowanej wartości kredytów udzielonych przedsiębiorstwom niefinansowym w walucie polskiej. Wykorzystano również informacje pochodzące z biuletynów informacyjnych NBP, portalów banków oraz publikacji Głównego Urzędu Statystycznego.

Mając na uwadze realizację celu głównego posłużono się rachunkiem korelacji linowej Pearsona [Chai i Draxler 2014] oraz zastosowano regresję liniową [Aleksader i Grabowski 2003]. Stopień dopasowania funkcji regresji zaś sprawdzono wykorzystując współczynnik determinacji [Trzesiok 2014]. W celu uzyskania przejrzystości wyników wykorzystano również metodę opisowo-tabelaryczną. 
Kluczowe zmienne w badaniu to zmienne objaśniane, takie jak oprocentowanie kredytów oraz wolumen kredytów udzielonych przedsiębiorstwom niefinansowym [Kufel 2011]. Ponadto wykorzystano stopy procentowe NBP jako zmienne objaśniające, tj.: referencyjna, lombardowa, redyskontowa i depozytowa.

\section{WYNIKI BADAŃ}

Analizę statystyczną przeprowadzono na podstawie danych historycznych dotyczących oprocentowania kredytów, stóp procentowych i sumy kredytów dla przedsiębiorstw niefinansowych w Polsce. W badaniu sprawdzono zależność oprocentowania kredytów i sumy kredytów, od stóp procentowych NBP. Z tego względu poziomy stóp procentowych zaklasyfikowano do predyktorów sumy kredytów w kwartalnych przedziałach czasowych obejmujących lata 2008-2015 (rysunek 1).

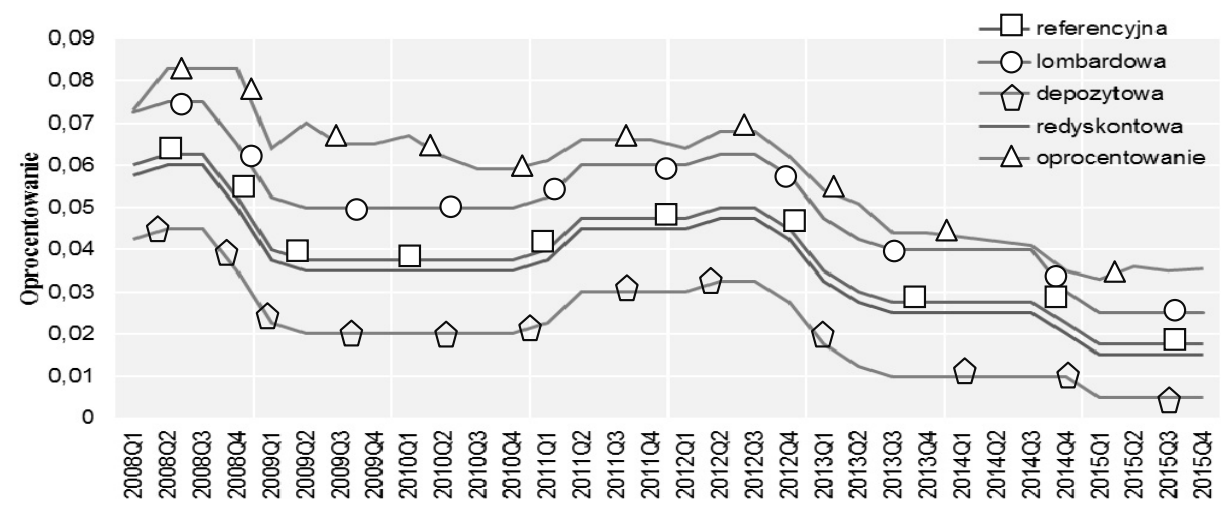

RYSUNEK 1. Stopy procentowe NBP oraz średnie oprocentowanie kredytów dla przedsiębiorstw niefinansowych w Polsce w latach 2008-2015, dane kwartalne

Źródło: Opracowanie własne na podstawie danych z comiesięcznych Biuletynów Informacyjnych przygotowanych przez NBP [dostęp: 20.02.2016].

Wstępna obserwacja zmienności oprocentowania kredytów dla przedsiębiorstw wykazała podobny charakter zmienności w relacji do stóp procentowych. Zmiany oprocentowania w poszczególnych kwartałach tych kredytów miały podobne tendencje, jak w przypadku stóp procentowych NBP.

W okresie badawczym można było zaobserwować spadek średniego oprocentowania kredytów o 2,7\% kwartalnie (rysunek 2). Podobne tendencje występowały w zmienności stóp procentowych, tj.: stopy referencyjnej o 3,4\%, stopy lombardowej $2,8 \%$, stopy depozytowej $6,1 \%$, stopy redyskontowej $3,3 \%$. Suma omawianych kredytów wykazywała wzrost o ok. 1,0\% kwartalnie. Zbliżone zmienności oprocentowania kredytów i stóp procentowych NBP mogą świadczyć 


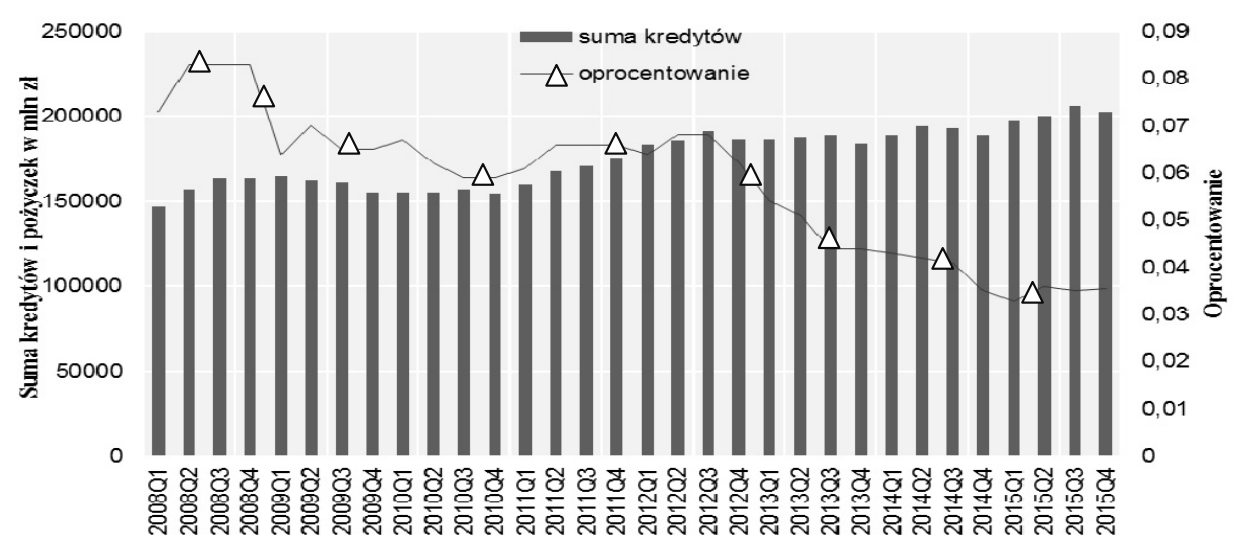

RYSUNEK 2. Wolumen kredytów udzielonych przez banki przedsiębiorstwom niefinansowym i ich przeciętne oprocentowanie w Polsce w latach 2008-2015

Źródło: Opracowanie własne na podstawie danych z comiesięcznych Biuletynów Informacyjnych przygotowanych przez NBP [dostęp online 20.02.2016].

o współliniowości zmiennych. Związki między zmiennymi opisano na podstawie współczynników korelacji dla wszystkich par zmiennych. Uzyskane wartości współczynnika korelacji między stopami procentowymi NBP a oprocentowaniem kredytów mają charakter zależności dodatniej, ponieważ stopy procentowe NBP w dużym stopniu kształtują stopy oprocentowania kredytów. Suma kredytów udzielonych przedsiębiorstwom niefinansowym wzrastała, podczas gdy poziom oprocentowania tych kredytów oraz stóp procentowych NBP malał. Zależności między sumą kredytów a stopami procentowymi NBP wykazują relacje ujemne, co potwierdza, że gdy następuje wzrost stopy procentowej, zmniejszeniu ulega suma zaciąganych kredytów przez przedsiębiorstwa. Zależność korelacyjna między stopą referencyjną a stopą lombardową oraz stopą lombardową a stopą dyskontową wyniosła 100\%. Podobna wartość występuje między stopą dyskontową a stopą referencyjną. Pozostałe zależności między stopami procentowymi wyniosły od 98 do 99\%. Zależność na tak wysokim poziomie wynika w praktyce z tego, że ich zmiana dokonywana jest przez ten sam organ (RPP), ponadto zmiany te dokonywane są $\mathrm{w}$ tym samym okresie, a kierunek zmian dokonywany jest o tym samym wektorze. Zależność oprocentowania kredytów od stopy referencyjnej, stopy dyskontowej, stopy lombardowej wyniosła 94\%. Zależność oprocentowania od stopy depozytowej wyniosła natomiast 93\%. Wyniki w tym zakresie oznaczają w praktyce ograniczone możliwości stosowania klasycznych metod analizy regresji na podstawie modeli z dużą liczbą zmiennych objaśniających. Wartości współczynnika korelacji występujące między oprocentowaniem kredytów a stopami procentowymi NBP świadczą o bardzo silnym związku miedzy zmiennymi 
[Kufel 2011, Trzesiok 2014]. Ponadto silna korelacja między stopami procentowymi może wskazywać na istnienie wariancji estymatorów, zatem zjawisko to wymaga wyeliminowania zmiennych skorelowanych w metodzie regresji wielorakiej, zatem estymacji parametrów modelu określającego relacje między oprocentowaniem kredytów a stopami procentowymi NBP oraz między sumą kredytów a oprocentowaniem kredytów i stopami procentowymi NBP dokonano przy wykorzystaniu funkcji regresji grzbietowej.

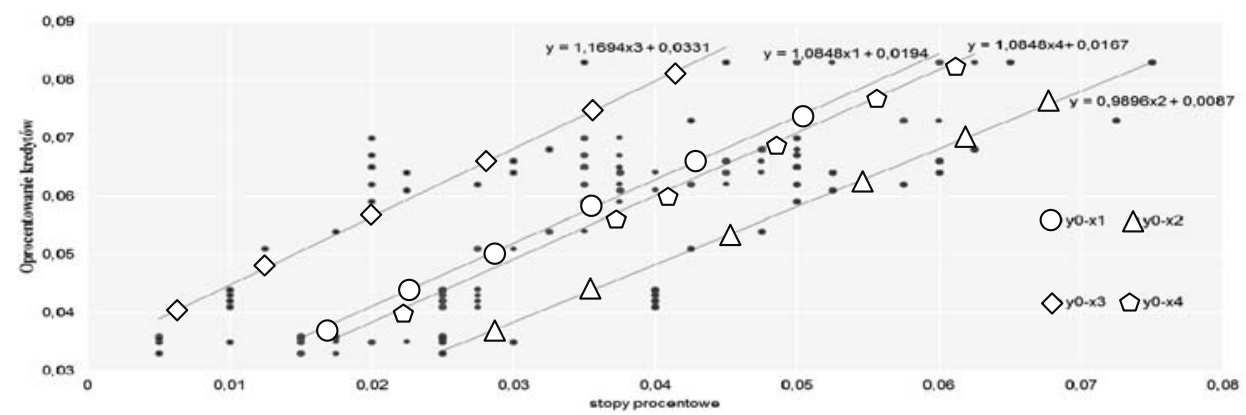

x1-y0 - oprocentowanie względem stopy referencyjnej, x2-y0 - oprocentowanie względem stopy lombardowej, x3-y0 - oprocentowanie względem stopy depozytowej, x4-y0 - oprocentowanie względem stopy redyskontowej, postać linii trendu ma charakter liniowy.

RYSUNEK 3. Korelacja oraz modele regresji grzbietowej między oprocentowaniem kredytów a stopami procentowymi NBP

Źródło: Badania własne w R-Project.

Zgodnie z oczekiwaniami suma kredytów wykazała odwrotną współzmienność w stosunku do oprocentowania kredytów i stóp procentowych NBP. Oznacza to, że spadek stóp procentowych NBP powodował wzrost popytu na kredyt wśród przedsiębiorstw niefinansowych. Charakter zależności między sumą kredytów a stopami procentowymi sprawdzono testem na liniowość zależności. Hipoteza mówiąca o występowaniu liniowej zależności w danym przypadku została odrzucona na rzecz hipotezy alternatywnej [Marek i Gatnar 2009].

Wynik testu istotności wartości współczynnika korelacji sumy kredytów i reszty zmiennych wykazał zależność istotną. W związku z tym hipoteza zerowa została odrzucona na rzecz hipotezy alternatywnej. A zatem takie zmienne jak stopy procentowe NBP i oprocentowanie kredytów kształtują sumę kredytów dla przedsiębiorstw niefinansowych. 


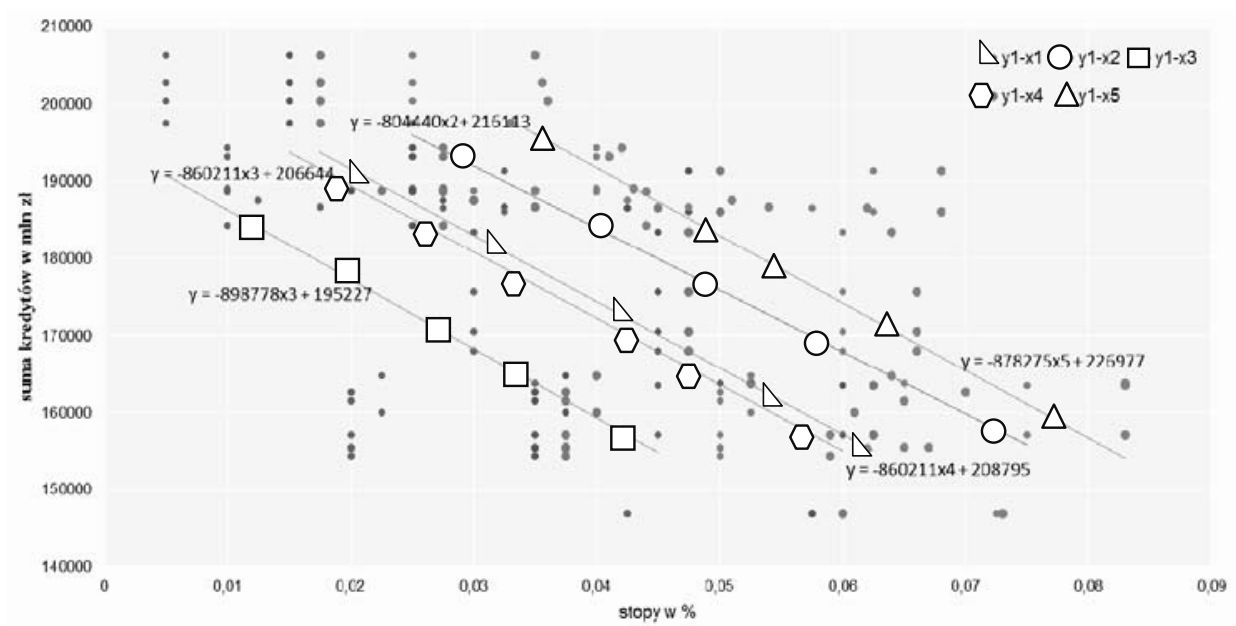

x1-y1 - suma kredytów względem stopy referencyjnej, x2-y1 - suma kredytów względem stopy lombardowej, x3-y1 - suma kredytów względem stopy depozytowej, x4-y1 - suma kredytów względem stopy redyskontowej, postać linii trendu ma charakter liniowy.

RYSUNEK 4. Korelacja oraz modele regresji grzbietowej między sumą kredytów a stopami procentowymi NBP

Źródło: Badania własne w R-Project.

\section{WNIOSKI}

Oprocentowanie kredytów dla przedsiębiorstw w latach 2008-2015 wykazało zależność względem kształtowania się podstawowych stóp procentowych NBP. Ustalono, że oprocentowanie kredytów zmienia się względem stóp procentowych NBP niemal bez opóźnień. Od czwartego kwartału 2008 roku do trzeciego kwartału 2009 roku, kiedy to zmiany stóp procentowych NBP wykazywały spadki, oprocentowanie zaczęło notować spadki z opóźnieniem jednego kwartału. W okresach stabilizacji stóp procentowych NBP, oprocentowanie kredytów na ogół nie zachowywało stabilności notując spadki swojego poziomu. Pozwala to uznać, że oprocentowanie kredytów dla przedsiębiorstw w analizowanym okresie zmieniało się w tym samym kierunku i mniej więcej w tym samym czasie, co stopy procentowe NBP.

Suma kredytów dla przedsiębiorstw niefinansowych w okresie badawczym nie podążała z taką samą dynamiką jak zmienność stóp procentowych NBP. Badanie zależności zmiennych wykazało, że suma kredytów jest w mniejszym stopniu zależna od zmian stóp procentowych NBP niż oprocentowanie kredytów od stóp procentowych banku centralnego oraz że zależność ta jest ujemna, tzn. kierunek zmian sumy kredytów jest przeciwny kierunkowi zmian stóp procentowych. 
Dynamika analizowanych zmiennych wskazuje, że trudno jest jednoznacznie stwierdzić, po jakim czasie od spadku stóp procentowych NBP nastąpi wyraźny wzrost sumy kredytów dla przedsiębiorstw niefinansowych. Problem określenia zależności między sumą kredytów a stopami procentowymi NBP w analizowanym okresie mógł być spowodowany kryzysem finansowym i innymi czynnikami zarówno po stronie banków jak i przedsiębiorstw niefinansowych. Spadek poziomu stóp procentowych NBP w okresie badawczym wyniósł około 70\% w przypadku każdej z podstawowych stóp. Oprocentowanie kredytu w tym samym czasie obniżyło swój poziom średnio o 51\%. Suma kredytów zaś wzrosła w analogicznym okresie o około 40\%. Może to świadczyć o popycie na kredyt nieadekwatnym do zmiany oprocentowania, mimo wyraźnych zachęt ze strony polityki Narodowego Banku Polskiego.

Od końca 2008 roku NBP utrzymuje tendencję spadających stóp procentowych. Jednak stopy te w Polsce nie osiągnęły wartości ujemnych, co należy ocenić pozytywnie. Niemniej istnieje prawdopodobieństwo, że korzyści z niskich stóp procentowych w postaci większego angażowania kapitału obcego przez przedsiębiorstwa sfery realnej w Polsce będą wraz z upływem czasu coraz większe.

\section{Spis literatury}

ALEKSANDER W., GRABOWSKI W. 2003: Ekonometria. Zbiór zadań, PWE, Warszawa.

CHAI, T., DRAXLER R. 2014: Root mean square error (RMSE) or mean absolute error (MAE), Geoscientific Model Development Discussions no. 7.

FLEJTERSKI S., MARCINKOWSKA M., WDOWIŃSKI P. 2014: Wpływ regulacji sektora bankowego na wzrost gospodarczy - wnioski dla Polski, Materiały i studia nr 305, Instytut Ekonomiczny, Warszawa.

IWANICZ-DROZDOWSKA M., JAWORSKI W., ZAWADZKA Z., 2010: Bankowość, zagadnienia podstawowe, POLTEXT, Warszawa.

JUSZCZYK S. 2008: Zdolność kredytowa w ocenie banku na przykładzie małych i średnich przedsiębiorstw [w:] Zeszyty Naukowe SGGW - Ekonomika i Organizacja Gospodarki Żywnościowej, nr 66, Warszawa.

KUFEL T. 2011: Charakterystyka procesów ekonomicznych [w:] Ekonometria. Rozwiązywanie problemów z wykorzystaniem programu GRETL, PWN, Warszawa.

MAREK W., GATNAR E. 2009: Statystyczna analiza danych z wykorzystaniem programu R, PWN, Warszawa.

TRZĘSIOK J. 2014: Porównanie zdolności predykcyjnych modelu regresji grzbietowej z wybranymi nieparametrycznymi modelami regresji [w:] Zastosowanie metod matematycznych w ekonomii i zarządzaniu, Uniwersytet Ekonomiczny w Katowicach, Katowice. 


\section{CHANGES IN INTEREST RATES AND VOLUME OF LOANS VERSUS CHANGES IN INTEREST RATES OF NBP IN YEARS 2008-2015}

Abstract. The aim of this study was to determine the evolution of the basic NBP interest rates and their impact on the change in the volume of loans to the non-financial corporations granted in Poland in the years 2008-2015. The analysis shows formation of the relationship between selected NBP interest rates, the volume of loans to non-financial corporations and the average interest rate on these loans. In the research were used statistical tools to establish relationships between variables. The results indicated presence of a strong relationship between changes in NBP interest rates and interest rate on loans to non-financial corporations. In addition, studies have shown that changes in interest rates has corresponded whit inadequate level of changes in the volume of loans to non-financial corporate sector.

Key words: monetary policy, the NBP interest rates, loans to businesses 